This is an Accepted Manuscript of an article published by Taylor \& Francis in The Design History on 12 May 2017, available online at:

http://www.tandfonline.com/doi/abs/10.1080/14606925.20

$\underline{17.1323426}$

Grace Lees-Maffei \& Daniel Huppatz, 'A Gathering of Flowers:

On Design Anthologies', The Design Journal, first published online 12 May 2017. 


\section{A GATHERING OF FLOWERS: ON DESIGN ANTHOLOGIES}

\section{Abstract}

Over the past decade, anthologies - also called 'readers' - of design history and theory have proliferated across publishers' catalogues. These books perform important pedagogical functions: they define fields and establish canons of authoritative texts, authors and concepts. While detractors argue that the easy availability of textual sources online means that we no longer need anthologies, the opposite argument can be made: the overwhelming volume of electronic information sharpens the need for concise, edited selections. This article examines the practices of selecting, editing and publishing anthologies and reasons for their increasing popularity, particularly in design education, at the present time.

\section{Keywords}

Design History; Design Studies; Design Culture; Anthologies; Pedagogy.

\section{Word Count 6045}

\section{INTRODUCTION: DEFINING ANTHOLOGIES}

The term 'anthology' has its etymological roots in the Hellenic Greek meaning a 'gathering of flowers', and it later referred to a gathering of poems. Today, 'anthology' refers to a published collection of writings, typically by various authors (OED Online 2016). In the modern period, anthologies - also called 'readers' or 'companions' - have been a mainstay of the publishing industry and they have been particularly prevalent in the teaching of language and literature, during a period 
which has seen the institution of English Literature as an academic subject. However, anthologies are found in almost every subject. Particularly over the past decade, anthologies of art and design history and theory have proliferated across publishers' catalogues. These books function to define disciplines and fields and establish canons of authoritative texts, authors and concepts. In this way, they perform an important pedagogical purpose. However, they may also appeal to practitioners and general readers who turn to such texts outside of formal educational contexts.

The practices of selecting, editing, publishing and distributing anthologies are acts of canon formation and are therefore freighted with significance. However, the very limited amount of reflective writing about the pedagogic value and limitations of anthologies has focussed principally in literary studies (Bloom 1997; Bloom 1999; Bloom 2000; Faigley 1992; Ferry 2001; Graff \& Di Leo 2000; Hawisher \& Selfe 1997; Leitch et al 2003; Price 2000) but also in other humanities disciplines such as geography (Johnston 2000 (a); Johnston 2000 (b)) and philosophy (Schrift 2000). The scholarship of learning and teaching in design higher education has largely focussed on the field's signature pedagogy of studio teaching, rather than on critical and cultural studies, with some exceptions (Orr et al 2004; Heatly et al 2005; de la Harpe \& Peterson 2009; Ryan 2009; Lichtman 2009; Huppatz \& Lees-Maffei 2013; Pollen 2015). In recognising a lack of reflexive writing on anthologies, Jeffrey $\mathrm{R}$. Di Leo has argued for 'critical discussion of anthologies [which] will ideally intermingle concern with their production, their ideological identity, their use by students and faculty, and the mechanisms that regulate their distribution and usage' (Di Leo 2004: 6). Anthologies, Di Leo argues, should be examined in relation to three topics: politics, pedagogy and economics, with the latter encompassing the material conditions of production and distribution within the publishing industry.

This article responds to Di Leo's call by examining the pedagogical benefits and drawbacks of design anthologies as well as the publishing industry context within which they appear. Such analysis seems particularly pertinent due to the paradoxical proliferation of print anthologies at the same time as the increasing digitization of pedagogical materials that have occurred over the past decade or so. Indeed, print anothologies can faciliate the production of digital academic products, as we will discuss. We have each edited separate anthologies of design history and therefore 
this article also represents a work of reflective practice, specifically in relation to the production of anthologies. We highlight the positive contributions of such anthologies and their limitations in the light of publishing and pedagogical assumptions and requirements.

\section{INDUSTRY CONTEXTS: EDUCATION}

Introducing his edited collection On Anthologies, Di Leo notes that 'Anthologies are shaped by pedagogies, and pedagogies are shaped by anthologies' (Di Leo 2004: 1 2). Anthologies have been mainstays of teaching because they pull together the best work in a field, however that quality might be defined, to provide a concise survey that is manageable within the confines of an academic course, whether of a term, semester, academic year, or degree in duration. Anthologies are, in short, selective and concise. Their very selectivity is cause for complaint by some, but is also their key benefit in other instances, as we shall discuss. In education, the published anthologies that proliferate today are usually accompanied by a tutor's own compilations, the course packs that teachers have laboriously prepared, photocopied, and which students have purchased for a fee to cover reprographic and copyright costs. However, with increasing digitisation, both tutors and academic libraries are increasingly offering textual materials to students online. For their course packs, tutors gather texts from a range of sources, often including anthologies comprised of texts that were gathered in turn by editors and publishers, thereby engaging layers of selection.

\section{Anthologies as Selective: Canon Formation}

By collecting, defining and framing key texts, an anthology functions as a repository for important documents and ideas on a given topic. At best, it introduces readers to new ways of thinking about a particular field by stretching its boundaries, critically examining common concepts or adding alternative perspectives. At worst, it confirms existing ways of thinking about a field by simply reinforcing an existing canon of authoritative works, authors or ideas with little critical reflection. Editorial decisions are important. For authors and for practitioners, inclusion or exclusion from an 
anthology may have a significant impact on their reputation. Readers assume that included texts are representative - even exemplary - of a particular time period, idea or group. A distinction must be made here between anthologies or readers which select from existing published sources and companions which offer newly commissioned material intended to cover a field (e.g. Sparke and Fisher 2016) or a combination of existing and new material (such as is planned for Triggs and Atzmon 2017).

In literature studies, scholarly reflection on anthologies and their role in the creation of a canon or tradition of universally admired works and authors has been around for some time (Harris 1991). The anthology's capacity for canon-formation is challenged, however, by philosopher Alan D. Schrift who argues that 'the project of totalizing canon creation is not only impossible but undesirable. We can only tell stories of what, now, seems important to recall, to bring together, to allow to speak for a little while longer (Schrift 2000: 175). Anthologies are by definition compact accounts of a larger story and, as reviewers will point out, are as much about exclusions as inclusions. Schrift also notes the temporal character of anthologies, as what are considered important inclusions change over time.

Given that anthologies shape what is read, discussed, and studied in educational contexts, critics have been driven by a concern for inclusions and exclusions. For an author, inclusion or exclusion in anthologies relates directly to the rise and fall of literary reputations. As well as the selection of a given work as authoritative, its inclusion in an anthology is also 'its introduction into an ongoing critical colloquy' (Harris 1991: 111). That is, inclusion involves the determination both of which works or authors are studied in educational institutions and which issues set the agenda for discussion. In the same manner, exclusion is not only of works and authors but issues and concepts.

Art historians have grappled with similar critiques and anxiety over inclusion and exclusion in anthologies, and have recognised that 'to canonize a set of objects, works or texts, means to declare that they are of the highest importance, as timeless models of their kind' (Locher 2012: 31). However, a weight of scholarship, including Marxist and feminist approaches in the 1970s and 1980s, and post-colonial, multicultural and queer theory approaches in the 1990s and 2000s, have challenged 
the idea of a singular or universal canon of masterworks (e.g. Pollock 1999; Brzyski 2007). Thus, the term 'canon' is now usually used in a critical manner (Locher 2012: 29). Certainly, scholarship over the past few decades has made editors wary of selecting key works or themes and of claiming a closed or universal collection. But anthologies as a form seem to be as popular as ever.

Perhaps the most important function of anthologies is pedagogical. Such critiques as are related above often arise out of concern for the phenomenon that Wendell Harris termed 'the principle of academic recirculation':

Academics tend to teach what they have been taught, what is easily available in print, what others are writing interestingly about, and what they themselves are writing about; what is easily available in print tends to be what is being taught and written about; what is written about tends to be what one is teaching or others are writing about (Harris 1991: 114).

Unlike in art or literary studies, the idea of an authoritative ranking of individuals and/or works in a canonical manner seems less important in the design world, in which designers work as part of teams, and as links in extended chains of ideation, manufacture, production, mediation, and consumption (Lees-Maffei 2009). Although the idea of a timeless, universal canon of great artists or writers does not apply in the same way, certainly issues of quality, taste, historical significance and the selection of objects worthy of study, are important for design in museum contexts, for example. But the crucial issue these critiques from other disciplines lend to design history, design studies and design cultures is a critical reflection on the editorial process of selection, the framework imposed upon the subsequent selection and the context in which an anthology is produced, distributed and read. Such criticism of 'canonization' forces us to ask difficult questions, to which we will return.

In editing the Design History Reader (Lees-Maffei and Houze 2010) I (Lees-Maffei) accepted the fact that anthologies cannot avoid the freighted exercise of canonformation, displaying the enthusiasms and prejudices of its editors while at the same time making sure that the notion of a canon of design writing, and indeed a canon of design, is interrogated and dismantled in editorial sections and some of the extracts included. In editing Design: Critical and Primary Sources, I (Huppatz) consciously 
strove to juxtapose opposing viewpoints in order to disrupt any sense of a coherent canon of design writing.

A key motivation for anthology editors is 'to compete' (Harris 1991: 118) - to challenge past and existing anthologies with an alternative perspective, an alternative collection. This strategy is risky. Famously, Thomas Kuhn has noted the role of textbooks in normalizing and propagating the current dominant intellectual paradigm in the sciences (Kuhn 1970 (1962)). Following Kuhn in considering the use of textbooks in the discipline of geography, R. J. Johnston has made clear that: 'Every textbook (other than one that successfully seeks to be comprehensive and "even-handed") is thus a "polemic", claiming authority for its particular viewpoint. Some are more polemic than others: those promoting a "new paradigm" are more so than those reworking one that is widely accepted and adhered to (Johnston 2000(a): 129).

With the Design History Reader, our (Lees-Maffei and Houze's) commitment to a broad understanding of design and our desire to address design history's methodological promiscuity meant that we sought to be inclusive in terms of the authors whose work we included. We paid attention to the proportion of women's writing included, for example, and we have tried to reflect both the lamentable Western bias of much design history of the twentieth century and the emergence of a globalizing imperative within the discipline. Finally, we showcased material from a wide range of fields, and some of our authors might well have been surprised to see their work included in an anthology of design history. While the Design History Reader reflects the preoccupations of its editors, no single method is dominant: rather, it introduces readers to a range of positions and methods and thereby fully exploits one of the core formal advantages of the anthology genre.

In editing Design: Critical and Primary Sources (Huppatz, 2016) I (Huppatz) was faced with an unusual brief - to map a larger field of knowledge across four volumes. Unlike previous single-volume anthologies, the four-volume format represented an opportunity to expand both the number of inclusions and the length of each one. While many previous anthologies included only excerpts of key articles or books, part of the aim of this collection was to include complete articles or book chapters. 
Given the scope and potential appeal of the broad field, "Design", the final compilation was arranged thematically rather than chronologically. An initial consideration - no doubt common to anthology editors - was how to achieve an appropriate balance between recognized "classic" readings by well-known authors and lesser-known or newer texts. As well as confirming the classics, an anthology can also spark new ways of thinking about a field.

The first volume, Design Reform, Modernism and Modernisation, aimed to establish historical foundations and themes that run through the set. The sources in the remaining three volumes aimed to encompass the scope of design activities in the late 20th and early 21 st centuries. This thematic overview, comprised of volumes devoted to Professional Practice and Design Theories, Social Interactions, and Development, Globalization and Sustainability, avoided the chronological structure of many previous anthologies. Instead, sources are arranged in thematic sections within which design is acknowledged as an emerging domain of knowledge with its own specificity, problems and shared assumptions.

The designer's voice is strong throughout the collection, from those engaged in more established professional practices such as industrial or graphic design to more recent practitioners of service design, design management and interaction design. These contributions are balanced by perspectives from scholars from a variety of disciplines including sociology, psychology, anthropology, management studies, history, philosophy and cultural studies. The interest in design across various fields attests to its contemporary relevance beyond practitioners, design educators and design researchers. Given contemporary design's dynamic nature, it is a field that is difficult to map with precision, and Design: Critical and Primary Sources is intended to foster dialogue structured around themes most relevant to those who practice, teach, research and think about design in the early 21 st century.

The extent to which the anthology format allows for the presentation of knowledge in a field as the result of multi-vocal and even multi-disciplinary engagement is questionable. In place of touted moves to polyvocality (McDowell 1994), Johnston perceives in the flurry of anthologies being produced in his field, geography, merely a shift from authorial authority to editorial authority (Johnston 2000(b): 277). He worries about the basis of this editorial authority, particularly when the editorial input 
involves excerpting the writings of others (the products of authorial authority). Johnston's concerns in this area lead him to reflect on the utility of the hybrid textbook/anthology, with narrative sections accompanied by selected texts or extracts. These, and courses based on them, are connected in his mind with the commodification of higher education, the efficiencies (or otherwise) of distance learning and his judgment that 'Rather than opening up the student mind - the classical view of education - the authoritative statements of received wisdom provided by such courses close it down' (Johnston 2000(b): 285).

However, the difficulty of such a position is its assumption of students and tutors as helpless, passive and uncritical readers. They are not. We contend that students rarely read anthologies from cover to cover and tutors do not use them uncritically. Rather, tutors encourage students to read actively and reflect upon the selections of texts as well as upon their content. Rather than simply or always constituting authoritative statements, anthologies also function as maps of a particular field, that ideally allow readers and tutors to explore sections and make their own paths through the selections. Additional information included in apparatus such as footnotes, bibliographies, introductions and guides to further reading (as in the Design History Reader) aids further exploration beyond the anthology, offering even more routes beyond Johnstone's 'authoritative statements of received wisdom'.

Digitial delivery of academic content will only faciliate this dynamic reading practice, as enhanced search functions and cumulative collections on content will allow greater movement, intellectually, around the material all within the convenient form of a subscription product, for example.

\section{INDUSTRY CONTEXTS: PUBLISHING IN PRINT AND ONLINE}

The popularity of anthologies in education has its correlative in the preponderance of anthologies in publishers' lists. Publishers favour anthologies because they sell well when they are used as set texts for large core courses, and they offer the efficiencies of recycling existing texts. Anthologies represent, to some, minimal work: all that is required is some editorial selection, a comparatively brief introduction and the arrangement of some permissions, although the latter can of course be decisive in 
shaping the anthology (Schrift, 2000: n.2). In fact, the economics of publishing anthologies are more complex than these suppositions allow (Nelson 2004). Issues of copyright permission, budgets and formats all affect anthologies. In arguing that anthologies are more than the sum of their parts, we contend that they bring extra benefits.

Aside from the economic considerations, when viewed within the context of the publishing industry another core issue becomes important in understanding the success of anthologies: digital dissemination. Detractors argue that the easy availability of a range of textual sources online means that we no longer need anthologies, or even printed books (Mekinda 2012). But the opposite argument can be made. The overwhelming volume of information now available electronically sharpens the need for concise, edited selections of texts. Toke Riis Ebbesen (2016) has demonstrated how print textbooks are pedagogically superior to their ebook replacements, which are often geared in their formats more towards persuading administrators to purchase multiple packages rather than meeting the needs of students. This returns us to the two core benefits of anthologies expressed above: they are selective and concise, as we shall explore further below.

In fact, anthologies are included as part of the print-based material which is gathered together in digital form to populate vast digital subscription products such as the Berg Fashion Library and the forthcoming Bloomsbury Design Library. These digital compendiums allow convenient online access to print book collections, using enhanced search tools and image library access, for members of subscribing institutions such as universities. The recent commissioning strategy of publishers such as Bloomsbury suggests that comprehensive titles such as Design: Critical and Primary Sources (Huppatz 2016), The Bloombsiry Encyclopedia of Design (Edwards 2016) and World History of Design (Margolin 2015) are intended both as print books in the first instance, and as content which will feed in to the digital Bloomsbury Design Library. Therefore, the relationship between print and digital is in this case extremely close, not to say symbiotic, with prnt providing the content for digital, and digital providing the business model to allow print to continue to flourish. 


\section{Anthologies as Concise: Abridgement, Omission and other Editorial Interventions}

Anthologies are necessarily reductive; they are the product of selection and distillation. Encyclopaedias are, by contrast, inclusive. Editors of anthologies share with editors of encyclopaedias a desire to be comprehensive, but this is achieved by anthology editors through a series of decisions which seek to remove everything unnecessary and allow only the relevant core to remain. Anthologies are, by their very nature, concise overviews. Encyclopaedia editors, on the other hand, are not under the same pressure to remove extraneous content; their task is as much acquisitive as it is selective. Notwithstanding these distinctions, anthologies and encyclopaedias are both often reviewed in terms of their inclusions and omissions, with critical reviewers focussing on the latter.

Philosopher Alan D. Schrift has defended anthologies as the product of both editorial intelligence and authorial intelligence (Schrift 2000). Editors produce intellectually meritorious anthologies that simultaneously create a tradition and showcase something new. In so doing they create a thesis or theses through the coherent selection of texts and this activity is one of authorial intelligence. Anthologies thereby complicate a simplistic binary that opposes pedagogy and scholarship by merging these two activities. Anthologies are often conceived to plug a scholarly gap but they also intervene in scholarship. They can spring from research questions and can result in books that form the bases for courses of study; they may thereby function as tangible bridges between research and teaching. For Schrift, a 'truly successful anthology' 'fills an intellectual void that even some of the practitioners of that scholarship don't yet realize exists' (Schrift 2000: 170). It does this, he argues, in part through its very form. The anthology replaces the singular voice with a range of voices and thereby overcomes the sense in which the 'cult of genius' ignores the influences of interlocutors and teachers on leading thinkers (Schrift 2000: 172). That is not to say that the range of an anthology is infinite; the 'textual finitude' of the form must be acknowledged and in any case, as we have noted above, readers of anthologies will use the selection in diverse ways, ignoring texts that they deem too difficult or irrelevant (Schrift 2000: 174). 


\section{ANTHOLOGISING DESIGN}

Design anthologies are relatively new. An early example was Tim and Charlotte Benton with Dennis Sharp's 1974 collection, Form and Function: A Source Book for the History of Architecture and Design, 1890-1939 (Benton et al 1974). Intended for pedagogical purposes, and developed as part of the course materials for the Open University's pioneering distance learning provision in design history, it contained short extracts and original translations of previously unavailable material. It is notable as one of the first anthologies of primary sources related to design, but, in retrospect, we can see that design is framed only in relationship to architecture in this text, and is an entirely Euro-American phenomenon. No notable design anthologies appeared for two decades, until Paul Greenhalgh's Quotations and Sources on Design and the Decorative Arts (1993) and, in our own century, Isabelle Frank's The Theory of Decorative Art: An Anthology (2000) and Carma Gorman's Industrial Design Reader (2003). Allworth Press produced a series of anthologies of writing on graphic design under the title Looking Closer (Beirut 1994; Beirut 1997; Beirut 1999; Beirut et al 2002, Beirut et al 2006), and another series of anthologies, edited by Victor Margolin and Richard Buchanan, presented selections of articles from the journal Design Issues that covered design history, theory and criticism (Margolin 1989; Margolin and Doordan 1995; Margolin et al 2010).

Carma Gorman, editor of The Industrial Design Reader (2003), noticed a new wave of anthologies when four were published in a period of just over a year: Ben Highmore's The Design Culture Reader and Fiona Candlin and Raiford Guins's The Object Reader, both published by Routledge in 2009, plus Hazel Clark and David Brody's Design Studies: A Reader and Grace Lees-Maffei and Rebecca Houze's The Design History Reader both published by Berg in 2009 and 2010 respectively. Gorman acknowledged the different emphases and audiences for the books, but saw enough commonality across the fields of design studies, cultural studies and design history to convene a panel at the College Art Association conference in 2010 in which the editors of these books reflected on the genesis, aims, selections, and intended audience for their respective titles ('By the Book: Towards a new paradigm of design studies?' a Design Studies Forum-sponsored session at the CAA conference, Chicago, 2010). In convening the panel, Gorman was concerned with 
how the extracts included in the anthologies related to disciplinary or interdisciplinary issues.

In this panel, Fiona Candlin explained that The Object Reader was not intended to present an overarching theme or argument but it did have an organising criterion for selection, namely: How do objects articulate in ways not expressible in language? The texts that Candlin and Guins selected, therefore, do not simply describe objects, rather they address the process self-reflexively. Similarly, Hazel Clark pointed out that Design Studies: A Reader, which she co-edited with David Brody, aimed to remove students from discipline-based thinking and limiting practice-based definitions, to consider shared issues relevant across design's sub-fields. The anthology, then, has the capacity to establish connections through proximity and juxtaposition; contiguity on the page points to intellectual contiguity in this model.

The Design History Reader is for students of design history, and students of design undertaking design historical study. It addresses design history as distinct from design studies. The convergence and divergence between these fields was the subject of a transatlantic debate that lasted nearly a decade from the mid-1980s to the mid-1990s, addressed in a dedicated section of the Design History Reader. There is a wealth of anthologies on specific design sub-disciplines, such as Carma Gorman's aforementioned Industrial Design Reader, and fashion and craft, for example have both been accorded dedicated anthologies (Welters and Lillethun 2007; Armstrong 2009; Adamson 2010). But design history is inclusive in its interests and encompasses the study of all of these, rising above silo thinking to understand design in multi-disciplinary ways. The core aim of representing design history holistically differentiates The Design History Reader from other anthologies in the field of design.

The editors' accounts at the CAA's 'Buy the Book?' conference panel responded, albeit perhaps inadvertently, to literary scholar David B. Downing's call for postdisciplinary approaches in the practice of teaching and anthologising knowledge. Downing has described anthologies as both 'theorizing the discipline' and 'disciplining' theory (Downing 2000). He identifies a contradiction: theoretical texts have the capacity to disrupt disciplinary boundaries but selecting them for an 
anthology 'disciplines' them. Anthologies are therefore symptomatic of a regulatory practice; they 'consolidate and discipline innovative new directions in theoretical discourse in order to make them understandable to a wider audience of English teachers, scholars and students' (Downing 2000: 131). Downing draws a parallel between the function of anthologies and that of paradigms. Noting that paradigms are more porous than Kuhn allows, Downing calls for the 'non-disciplinary and postdisciplinary practices [that] often already comprise the larger part of our working lives' to be more widely recognised in the organisation of knowledge, curricula and teaching, including the practice of anthologising that knowledge.

Anthologies respond to the interests of the time in which they are compiled, and the organising principles of knowledge change over time. For a discipline such as literary studies, the ideas of primary and secondary sources seems clear - a piece of fiction or poetry as a primary source, with criticism about these as secondary. But for design, the situation is not so clear. Indeed, the question of what might constitute a primary source for design is a vexed one - it may be a drawing, plan or model, that is, an object. Or we could consider theoretical or reflective writings by designers as primary sources, and criticism of finished projects or design processes by cultural commentators (often from a variety of disciplinary backgrounds) as secondary. Regardless, one limitation of design anthologies - driven by the publishing industry is the lack of images in many of the design anthologies noted above, with The Design History Reader (Lees-Maffei and Houze 2010) being an exception.

\section{CONCLUSION: OVERCOMING THE THEORY/PRACTICE SPLIT}

This article has presented the anthology as the product of two mutually-reliant industries: education and publishing. Anthologies are popular with teachers at all levels because they are selective and concise; they make disciplines and fields manageable within the temporal, intellectual and practical confines of academic study. Anthologies are perennial components of publishers' lists because they are cost-effective; they require less effort on the part of publishers to produce than newly authored monographs, for example, and they sell well as set texts to a core market. We have reviewed some of the core considerations at stake in the preparation, 
circulation and use of anthologies, particularly within the fields of art and design higher education. It is in this latter context, particularly, that we want to conclude.

Because anthologies are selective and concise they offer specific benefits to the community of art and design students in higher education. Many have chosen their fields of study precisely because they promise a principally visual or material mode of communication, rather than the textual focus, or logocentrism, of much higher education. This situation underpins the much-lamented and indeed contested theory/practice split in art and design higher education (Pollen 2015). In this context, anthologies offer students resources which tax them as little as possible and provide as much pedagogical benefit as possible, in terms of editorial introductions framing the material, editorial interventions strengthening the core messages, supporting materials in the form of further guided reading, and helpful apparatus such as timelines and indexes. Teachers, and publishers, are conscious of the need to cater for students who rely less and less on the book as a way of gathering information.

Anthologies, like encyclopaedias, are eminently suited to being broken up into their constituent texts for inclusion in digital libraries such as the Berg Fashion Library and the forthcoming Bloomsbury Design Library. Presumably, the future of anthologies will be digital rather than print-based, but we believe they will remain crucial as guides for students navigating a potentially overwhelming mass of digital information. For now, anthologies are ideal tools for today's students and teachers; they offer a carefully edited selection of writings that have already demonstrated their success and impact, and guidance on further reading. The - usually - excerpted form of the selected texts caters both to students' desires for expediency and the teachers' desires that students should read widely. Far from representing art and design history 'lite', the editors of these books actively create richer intellectual environments for learners. Therefore, it is no surprise that they remain popular and have, indeed, become more prevalent during the period of the visual and material turns and in the digital era. 


\section{REFERENCES}

Adamson, Glenn. 2010. The Craft Reader. Oxford: Berg.

Armstrong, Helen ed. 2009. Graphic Design Theory: Readings from the Field. New York: Princeton Architectural Press.

'By the Book: Towards a new paradigm of design studies?' a Design Studies Forumsponsored session at the CAA conference, Chicago, 2010.

Benton, Tim and Charlotte Benton with Dennis Sharp, eds. 1974. Form and Function: A Source Book for the History of Architecture and Design, 1890-1939, London: The Open University.

Bierut, Michael, William Drenttel, Steven Heller and DK Holland, eds. 1994. Looking Closer: Critical Writings on Graphic Design, New York: Allworth Press.

Bierut, Michael, William Drenttel, Steven Heller and DK Holland, eds. 1997. Looking Closer 2: Critical Writings on Graphic Design, New York: Allworth Press.

Bierut, Michael, Jessica Helfand, Steven Heller, William Drenttel, and Rick Poynor, eds.1999. Looking Closer 3: Classic Writings on Graphic Design, New York: Allworth Press.

Bierut, Michael, William Drentell and Steven Heller, eds. 2002. Looking Closer 4: Critical Writings on Graphic Design, New York: Allworth Press.

Bierut, Michael, William Drentell and Steven Heller, eds. 2006. Looking Closer 5: Critical Writings on Graphic Design, New York: Allworth Press.

Bloom, Lynn Z. 1997. 'Making Essay Connections: Editing Readers for First-Year Writers' in Gary A. Olsen and Todd W. Taylor, eds., Publishing in Rhetoric and Composition, pp. 133-146, Albany, N.Y.: State University of New York Press. 
Bloom, Lynn Z. 1999. 'The Essay Canon', College English 61(4); 401-430.

Bloom, Lynn Z. 2000. 'Once More to the Essay: the Essay Canon and Textbook Anthologies', Symploke 8(1-2): 20-35.

Brzyski, Anna, ed. 2007. Partisan Canons. Durham and London: Duke University Press.

Candlin, Fiona and Raidford Guins, eds. 2009. The Object Reader. Abingdon: Routledge.

Clark, Hazel and David Brody, eds. 2009. Design Studies: A Reader. Oxford: Berg.

Cooper, Rachel, Sabine Junginger \& Thomas Lockwood, with Richard Buchanan, Richard Boland and Kyung-won Chung, eds. 2011. The Handbook of Design Management. Oxford and New York: Berg.

de la Harpe, Barbara and J. Fiona Peterson. 2009. 'Through the learning and teaching looking glass: What do academics in art, design and architecture publish about most?' Art, Design and Communication in Higher Education 7(3): 135-54.

Di Leo, Jeffrey R., ed. 2004. On Anthologies: Politics and Pedagogy, Lincoln and London: University of Nebraska Press.

Downing, David B. 2000. 'The "Mop-up" Work of Theory Anthologies: Theorizing the Discipline and the Disciplining of Theory' symploke 8(1-2): 129-150.

Ebbesen, Toke Riis. 2016. 'The Systime iBog: Analysing Digital Textbooks as Designed Artefacts' Logos 27(3): 11-22.

Edwards. Clive ed. 2016. The Bloombsury Encyclopedia of Design (3 vols). London: Bloomsbury Academic. 
Faigley, Lester. 1992. 'Coherent Contradictions: The Conflicting Rhetoric of Writing Textbooks', Fragments of Reality: Postmodernity and the Subject of Composition, pp. 132-62, Pittsburgh: University of Pittsburgh.

Ferry, Ann. 2001. Tradition and the Individual Poem: An Inquiry into Anthologies, Stanford, CA: Stanford University Press.

Frank, Isabelle, ed. 2000. The Theory of Decorative Art: An Anthology, Yale University Press.

Gorman, Carma, ed. 2003. Industrial Design Reader, New York: Allworth Press.

Graff, Gerald and Jeffrey R. Di Leo. 2000. 'Anthologies, Literary Theory and the Teaching of Literature: An Exchange', symploke 8(1-2): 113-128.

Grand, Simon \& Wolfgang Jonas, eds. 2012. Mapping Design Research. Basel: Birkhäuser.

Greenhalgh, Paul, ed. 1993. Quotations and Sources on Design and the Decorative Arts, Manchester: Manchester University Press.

Harris, Wendell. 1991. "Canonicity”, PMLA, 106(1): 110-121.

Hawisher, Gail E., and Cynthia L. Selfe. 1997. 'The Edited Collection: A Scholarly Contribution and More', in Gary A. Olsen and Todd W. Taylor eds., Publishing in Rhetoric and Composition, pp. 103-118, Albany, N.Y.: State University of New York Press.

Heatly, Richard, Tracy Pritchard and Keith Trigwell. 2005. 'How art, media and design students conceive of the relation between the dissertation and practice,' Art, Design and Communication in Higher Education 4(1): 5-15.

Highmore, Ben. 2009. The Design Culture Reader. Abingdon: Routledge. 
Huppatz, D. J. and G. Lees-Maffei. 2013. 'Why Design History? A Multi-National Perspective on the State and Purpose of the Field,' Arts and Humanities in Higher Education 12(3): 310-330.

Huppatz, D.J. 2016. Design: Critical and Primary Sources. London: Bloomsbury.

Johnston, R.J. 2000(a). 'On Disciplinary History and Textbooks: or Where Has Spatial Analysis Gone?' Australian Geographical Studies 38(2):125-137.

Johnston, Ron. 2000(b). 'Authors, Editors and Authority in the Postmodern Academy', Antipode 32(3): 271-291.

Kuhn, T. S. 1970 (1962). The Structure of Scientific Revolutions, University of Chicago Press, Chicago.

Lees-Maffei, Grace. 2009. 'The Production-Consumption-Mediation Paradigm', Journal of Design History 22(4): 351-376.

Lees-Maffei, Grace \& Rebecca Houze, eds. 2010. The Design History Reader. Oxford: Berg.

Leitch, Vincent B., Barbara Johnson, John McGowan, Laurie Finke, Jeffrey J. Williams. 2003. 'Editing a Norton Anthology', College English 66(2): 172-206.

Lichtman, Sarah A. 2009. 'Reconsidering the History of Design Survey', Journal of Design History, 22(4): 341-350.

Locher, Hubert. 2012. "The Idea of the Canon and Canon Formation in Art History", in Matthew Rampley, ed., Art History and Visual Studies in Europe: Transnational Discourses and National Frameworks, pp. 29-40. Leiden and Boston: Brill.

Margolin, Victor. ed. 1989. Design Discourse: History, Theory, Criticism. Chicago: University of Chicago Press. 
Margolin, Victor and Richard Buchanan, eds. 1995. The Idea of Design, Cambridge, Mass: MIT Press.

Margolin, Victor, Richard Buchanan and Dennis P. Doordan, eds. 2010. The Designed World: Images, Objects, Environments, Oxford and New York: Berg.

Margolin, Victor. 2015. World History of Design (2 vols.) London: Bloomsbury Academic.

McDowell, L. 1994. 'Polyphony and Pedagogical Authority', Area 26: 241-248.

Mekinda, Jonathan. 2012. Review of The Design History Reader. Journal of Design History: 25(4): 431-433.

Meroni, Anna \& Daniela Sangiorgi, eds. 2011. Design for Services. Farnham: Gower.

Nelson, Cary. 2004. 'The Economic Challenges to Anthologies', in Jeffrey R. Di Leo, ed., On Anthologies: Politics and Pedagogy, pp. 170-185, Lincoln and London: University of Nebraska Press.

OED Online. 2016. "anthology, n.". June 2016. Oxford University Press. http://www.oed.com/view/Entry/8369? redirectedFrom=anthology (accessed July 05, 2016).

Orr, Susan, Margo Blythman and Joan Mullin. 2004. 'Textual and visual interfaces in art and design education,' Art, Design and Communication in Higher Education 3(2): 75-80.

Pollen, Annebella. 2015. 'My Position in the Design World: Locating Subjectivity in the Design Curriculum' Design and Culture 7(1): 85-105.

Pollock, Griselda. 1999. Differencing the Canon: Feminist Desire and the Writing of Art's Histories, London and New York. 
Price, Leah. 2000. The Anthology and the Rise of the Novel: From Richardson to George Eliot, Cambridge: Cambridge University Press.

Ryan, Nicky. 2009. 'Millstone or Milestone? The perceived value of cultural studies for art and design students and teachers,' Art, Design and Communication in Higher Education 8(1): 9-25.

Schrift, Alan D. 2000. "'Confessions of an Anthology Editor', symploke 8(1-2): 164176.

Sparke, Penny and Fiona Fisher, eds. 2016. The Routledge Companion to Design Studies. Abingdon: Routledge.

Triggs, Teal and Leslie Atzmon. 2017. The Graphic Design Reader. London: Bloomsbury Academic.

Welters, Linda and Abby Lillethun, eds. 2007. The Fashion Reader. Oxford: Berg. 